\title{
Quality Enhancement of Corporate Management Systems: An Overview of Best Management Practices
}

\author{
Giron Kamonja1 ${ }^{*}$, Yan Liang1, Muhammad Tayyab Sohail2, Shahzad Ahmad Khan1 \\ ${ }^{1}$ School of Economic and Management, China University of Geosciences (Wuhan), Wuhan, China \\ ${ }^{2}$ School of Public Administration, China University of Geosciences (Wuhan), Wuhan, China \\ Email: "gkamonja2001@yahoo.fr, tayyabsohail@yahoo.com
}

Received 25 April 2014; revised 21 May 2014; accepted 15 June 2014

Copyright (C) 2014 by authors and Scientific Research Publishing Inc.

This work is licensed under the Creative Commons Attribution International License (CC BY).

http://creativecommons.org/licenses/by/4.0/

(c) $($ i) 0 pen Access

\begin{abstract}
In this my present study, I elaborate different types of management, management staffs, types of managers and leaders along with their capacities of work and their roles in any organization or institute to achieve the desired goal with the help of employees. A study found that most of the CEOs of the 62 major US-based companies spent at least 10 percent of their time in quality enhancement efforts. The critical importance of employees' involvement in the quality process of an organization is based on the belief that the best process innovation ideas come from the people actually doing the job. Employee involvement in quality efforts can only come about when the employees know that the organization cares for them. Best companies do not just confine education and training to their shop floor employees and managers. Top executives are actively involved in the learning process themselves. Training is the key element of management system. For the smooth run of any organization we always need proper training for all employees including leadership authority.
\end{abstract}

\section{Keywords}

Management, Training, Quality, Management Practice

\section{Introduction}

\subsection{Senior Managers' Role}

Based on Malcolm Baldrige National Quality Award (MBNQA) deep lying analysis, Easton [1], in capturing the state of leadership of top management in the Baldrige applicants, states that senior management is committed to

\footnotetext{
${ }^{*}$ Corresponding author.
}

How to cite this paper: Kamonja, G., Liang, Y., Sohail, M.T. and Khan, S.A. (2014) Quality Enhancement of Corporate Management Systems: An Overview of Best Management Practices. Journal of Service Science and Management, 7, $302-312$. http://dx.doi.org/10.4236/jssm.2014.74027 
quality. Senior managers are actively involved in promoting the importance of quality and customer satisfaction and they devote a substantial part of their time to quality-related issues. Their involvement includes activities such as meeting with employees, meeting with customers, giving formal and informal recognition, and receiving training and training others. Senior management also develop and communicate key company quality values which place emphasis on the importance of the customer, process orientation, continuous improvement, teamwork, management-by-fact, mutual respect and dignity, and value of individual employees and their contributions. They ensure that the entire workforce understands its role in satisfying the customer. To support and promote the quality process of the organization, senior management develops and puts in place elements of quality management structure. These include a senior management TQM council or division and departmental councils (Figure 1).

Discussions of implementation case studies in the literature are also unanimous in reinforcing this reality. The examples range from large to small companies, service to manufacturing, multinationals to family business, and government to non-profit agencies [2]. At ICL Product Distribution UK, the chief executive and senior executives spearheaded the company-wide quality drive; while at Ciba Geigy Italy, the total quality initiative was led by the group chief executive, with the active support and involvement of senior executives [3]. It is the same for CCTEC metallurgical company in China (Wuhan).

\section{Senior Management's Specific Mission}

First and foremost in the quality evolution process, senior management must start by understanding what TQM really means [4]. They must be well aware of the benefits to the organization and acknowledge the fundamental change which will bring in the running of that organization. It is critical that they build the requisite commitment before getting the rest of the staff involved. There must be consensus among them regarding what the organization needs to achieve its quality goal.

At the Aluminum Company of America (Alcoa), it was the chief executive officer who initiated the quality initiative. The directors and senior managers then labored over six months to identify the challenges and opportunities, and then to design and begin the total quality process there. During this period, the top management team, including the CEO, spent many hours in quality education, training, visiting and benchmarking companies that had acquired reputations as leaders in quality management. All these helped form a consensus among top management about why were they interested in quality and what they need to get done to achieve the goals [5].

\subsection{Seniors Executives' Behavior}

One of the precepts of TQM is employees' greater involvement and commitment to the process and its goal. It is through the actions and behavior of the management that employees identify with the goals of the company and extend their commitment towards its success [6]. Ramirez and Loney's [7] study also highlighted the fact that it is not sufficient for management just to be committed, but they must also be obvious [8]. Bertsch and Williams' [9] study also found that senior executives see being visible in their commitment to quality sends strong signals about what is expected and desired from the staff. It is through their demonstrated actions and behavior that management can harness the involvement of employees corresponding to the necessary skills, and thence their commitment to the quality goals of the company not only will be assured but also will achieve as the senior executives might be expected [10]. Johnston and Daniel [11] in relating Fuji Xerox experiences, stress that if top

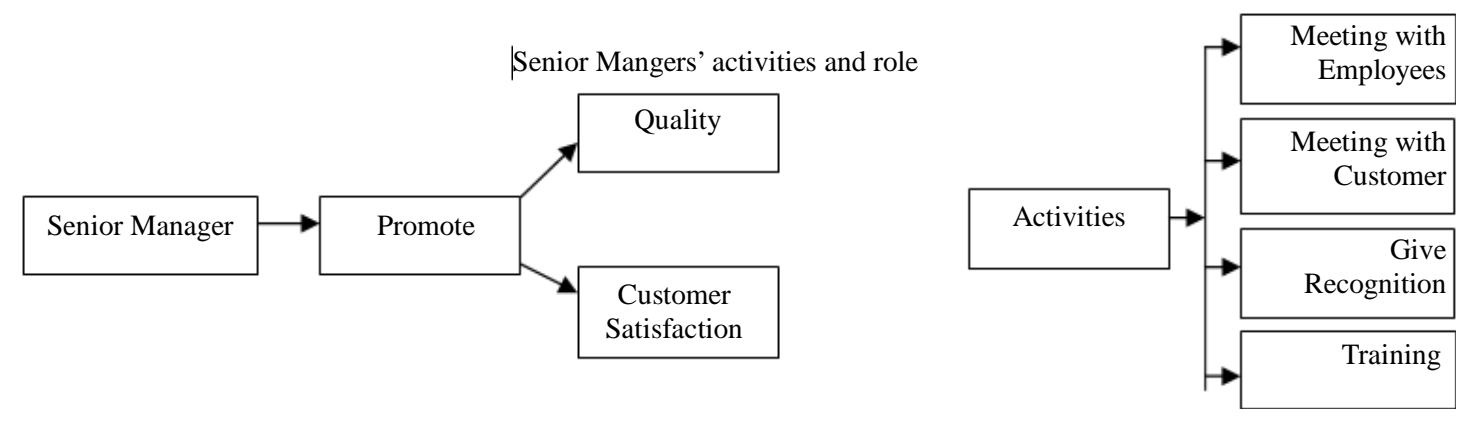

Figure 1. Senior managers'activities and role. 
management command employees to improve but are not themselves constantly seeking ways to improve systems, continuous improvement initiatives will fail. In describing the experiences of TQM implementation at Johnston Matthey plc, UK, George [12] emphasizes that senior management demonstrating involvement in the quality process is just as critical as commitment. There were initial hiccups in the implementation process when staff felt that senior executives were not committed [12]. This experience represents tangible proof, it is imperative to respect the hierarchy provided in the command structure. The violation of the commandment line either horizontal or vertical can harm mutual respect between subordinate and hierarchical superior and ultimately will lead to the disobedience leader in question.

The CEO of Alcoa stressed the need for his directors and senior managers to be visible in terms of their commitment in the eyes of the staff involved [5]. The findings of a survey carried out among employees at two Hewlett-Packard factories in the UK, disclosed the degree of buy-in amongst the respondents was favorable amongst those who saw their management staff using the TQM techniques themselves to improve processes [13].

\section{Relationship of the Tasks between CEO and Senior Executives}

Some of the ways CEOs and senior executives of best companies make this commitment evident is by leading quality initiatives and investing the requisite time and effort. A study found that most of the CEOs of the 62 major US-based companies spend at least 10 percent of their time in quality improvement efforts [6]. At Southern Pacific Lines, leadership meant role modelling. This involved leaders being out on the "track and yards" with the employees to demonstrate and speak about the quality-driven approach to doing business [14]. The CEO of Motorola spent a significant amount of time explaining the corporate vision to enable every employee to translate it into personal work goals [15]. The president and his senior executives at Shorts Brothers were the first to be trained in the theory, practice and tools of quality improvement [16]. The managing director of Rockware Glass Ltd. UK meets every employee in a series of TQM-related sessions at various locations and times convenient to the workers [17]. A high-powered steering committee to manage the TQM process at Paul Revere Insurance Group is a visible sign of top-level commitment to the process [18]. The vice-president at Philips Electronics personally leads a company-wide task force on quality improvement of software development, while at Ericsson Sweden; a top executive took ownership of analyzing and improving the order-make-market system [9].

\subsection{Role and Responsibilities of Chief Executive Officer (CEO)}

The Chief Executive Officer ("CEO") is responsible for leading the development and execution of the Company's long term strategy with a view to creating shareholder value. The CEO's leadership role also entails being ultimately responsible for all day-to-day management decisions and for implementing the Company's long and short term plans. The CEO acts as a direct liaison between the Board and management of the Company and communicates to the Board on behalf of management. The CEO also communicates on behalf of the Company to shareholders, employees, Government authorities, other stakeholders and the public.

\subsubsection{The Main Task of the Responsible CEO}

According to Juran [19], there are seven steps that a responsible CEO must take to achieve quality in any organization:

1) Set up and serve on the company's quality council.

2) Establish corporate quality goals and make them a part of the business plan.

3) Make provision for training the entire company hierarchy in managing for quality.

4) Establish the means to measure quality results against quality goals.

5) Review results against goals on a regular basis.

6) Give recognition for superior quality performance.

7) Revise the reward system to respond to the changes demanded by world class quality.

Oakland [20] lists the five requirements for effective leadership:

1) Clear beliefs and objectives in the form of a mission statement.

2) Clear and effective strategies and supporting plans.

3) The critical success factors and critical process. 
4) The appropriate management structure.

5) Employee participation through empowerment, the EPDCA (Evaluate, Plan, Do, Check, Amend) helix.

\subsubsection{Specifics Responsibilities of the CEO}

More specifically, the duties and responsibilities of the CEO include the following:

1) to lead, in conjunction with the Board, the development of the Company's strategy;

2) to lead and oversee the implementation of the Company's long and short term plans in accordance with its strategy;

3) to ensure the Company is appropriately organized and staffed and to have the authority to hire and terminate staff as necessary to enable it to achieve the approved strategy;

4) to ensure that expenditures of the Company are within the authorized annual budget of the Company;

5) to assess the principal risks of the Company and to ensure that these risks are being monitored and managed;

6) to ensure effective internal controls and management information systems are in place;

7) to ensure that the Company has appropriate systems to enable it to conduct its activities both lawfully and ethically;

8) to ensure that the Company maintains high standards of corporate citizenship and social responsibility wherever it does business;

9) to act as a liaison between management and the Board;

10) to communicate effectively with shareholders, employees, Government authorities, other stakeholders and the public;

11) to keep abreast of all material undertakings and activities of the Company and all material external factors affecting the Company and to ensure that processes and systems are in place to ensure that the CEO and management of the Company are adequately informed;

12) to ensure that the Directors are properly informed and that sufficient information is provided to the Board to enable the Directors to form appropriate judgments;

13) to ensure the integrity of all public disclosure by the Company;

14) in concert with the Chairman, to develop Board agendas;

15) to request that special meetings of the Board be called when appropriate;

16) in concert with the Chairman, to determine the date, time and location of the annual meeting of shareholders and to develop the agenda for the meeting;

17) to sit on committees of the Board where appropriate as determined by the Board; and

18) to abide by specific internally established control systems and authorities, to lead by personal example and encourage all employees to conduct their activities in accordance with all applicable laws and the Company's standards and policies, including its environmental, safety and health policies.

\section{Internal Stakeholders' Management}

\subsection{Employee Involvement}

While top management involvement and leadership are essential for TQM success, they are not sufficient on their own [21]. TQM succeeds only with employees' involvement in the TQM process and their commitment to its goals [8] [18] [22]. In 1979, when the founder president of Matsushita Japan spoke of how Japanese products swept aside Western products in the world market, he attributed it to the involvement of everyone in the company in the quest for quality [18]. This fact was also captured in a study which found that organizations with a high level of employee involvement stand a greater chance of success [23]. Crosby [24] talks about the need for every individual in the organization to understand his or her role in making quality happen. In fact, the need to maximize the involvement of all employees is one of the basic principles of change implementation in an organization. It involves the employees having a common understanding of quality and the importance of their involvement to maintain the quality momentum.

\subsubsection{Importance of Labor in Quality Process}

According to the chief executive of Federal Express, the foundation for the success of the quality improvement process at this company is the involvement of every employee in that process [25]. He calls it the "human side 
of quality". LeaRonal (UK) believes that "for a quality improvement program to be successful, the commitment to total quality must encompass a whole workforce who must be encouraged to participate actively in the search for continuous improvement" [26]. The success of the quality improvement process at Mitel Telecom Ltd. UK is attributed to the total involvement of the workforce [27]. In implementing the quality process, Shorts Brothers views greater involvement of its workforce as important evidence that the company is progressing in the right direction [16].

The critical importance of employees' involvement in the quality process of an organization is based on the belief that the best process innovation ideas come from the people actually doing the job [21]. The quality reputation of Japanese companies is mainly credited to their great success in this area.

\subsubsection{Labor Empowerment Result}

A total quality environment demands that people participate in continuous improvement activities in an unhindered manner, that pushing decision making to the lowest practical level is the way. In TQM terminology, this is called "empowerment". Deming [28] and Juran [29] also stress the importance of empowerment or giving employees the authority and autonomy to do their job when they talk about "pride of workmanship", "self-improvement", "self-control" and "self-inspection" respectively. At Tioxide Group Limited, empowerment to enable its employees to participate in continuous improvement activities was seen as a key element in the development of its total quality strategy [16].

Zink [30] emphasizes that employee empowerment is an important area of assessment of major quality awards around the world. Empowered employees go by many labels: self-managing teams, self-directing teams, autonomous groups. Zink [30] even includes participation in employee suggestion schemes.

\subsubsection{Advantages of Labor Conscientious}

Promoting employee involvement by operating employee suggestion schemes is common in the majority of the 158 US companies in the Fortune 1000 surveyed (Conference Board in Olian and Rynes [6]). While such schemes are also common in non-TQ organizations, enthusiasm is often stifled due to poor follow-up from management. TQ organizations, however, generally design schemes that are responsive and user-friendly. Employees who wish to make a suggestion at Thomas Interior Systems simply fill out a half-page pre-printed form and drop it in a designated suggestion box [11]. Response to the suggestions is ensured within 72 hours. At Thomas, ideas are submitted at an average monthly rate of 40, with an implementation at 80 percent.

At Milliken, which received 262,000 ideas in 1989, suggestions are acknowledged within 24 hours and acted on within 72 hours, while at Globe Metallurgical, ideas discussed at the weekly quality circle meeting are implemented the same day where possible [31]. However, at Eastman Chemical Company, the suggestion system was eliminated because it was found to impede teamwork [32].

Greater employee involvement in quality efforts can only come about when the employees know that the organization cares for them [25]. Baldrige winners treat their employees as partners rather than hired hands [31]. The chief executive of Wainwright Industries, the 1994 winner of the Baldrige Award, sums up this point well when he said: "An internal customer (employee) will treat the external customer the way he or she is treated by the company" [33]. This message is echoed by Townsend and Gebhardt [25], "Without the co-operation of the latter group (employees), the loyalty of the former (external customers) is always in jeopardy".

\section{Middle Management Role}

The act of maximizing employee involvement in the quality process requires middle managers within the organization to make major adjustments. They must give up some authority as power and control are pushed to lower levels in the organization. In addition, managing according to the philosophy of TQM requires new attitudes and skills from middle managers [34]. The transition towards TQM can be an uncertain and troubling process for middle managers [25] [35]. Only when middle managers are convinced that the transition process that may cost them in status, power and recognition leads to a better world, can the implementation of TQM be smooth. If they do not see it, they may react with suspicion, uncertainty and resistance [17] [34] [36]. Crosby [24] says "It is hard to get people interested in improvement of any kind if they perceive it is a threat to their authority or life style." Unless there is a middle management buy-in, they soon become barriers to rather than champions of the new system. According to Manz and Sims [35], "On the road to a total quality culture, the biggest obstacle to success is the middle management brick wall”. 


\subsection{Middle Manager's Functions}

It is in this sense that Saritha Pujari tried to define the main functions of Middle Managers, namely:

1) Interpreting Policies:

At this level, policies framed by top-level managers are interpreted. Like the marketing manager introduces his salesmen to the sales policy of the company that at no cost credit sales will be made.

2) Preparing Organizational Set-Up:

Every middle-level manager prepares outline of his respective department in accordance with the objectives of the organization.

3) Appointing Employees:

Every departmental manager appoints employees to fulfill the activities of his department.

4) Instructor:

Departmental managers direct their subordinates about what to do and how they have to do it. Needful resources are made available to subordinates so that they can do the assigned jobs uninterrupted.

5) Motivating Employees:

Middle-level managers motivate their employees by various means so that they work most efficiently to achieve organizational objectives.

6) Cooperation with Employee:

Cooperation among different divisions is required to successfully achieve company's objectives and this is done by middle level managers.

This fact was also reflected in a survey of 161 organizations. It was established that one of the elements that differentiated the successful TQ organizations from the less than successful ones was middle management support. A survey concluded that without middle managers' committed support for the quality process, the process will be derailed.

\section{Specific Function of Middle Managers}

Another survey reported in Quality Progress [37], which examined 536 organizations using TQM, returned similar findings. The study, which aimed to identify specific practices that have contributed to or detracted from TQM success, revealed that middle management are the main roadblocks to successful TQM. The study recommends that senior management should work hard to understand and involve middle managers in TQM efforts such as involvement in designing and promoting TQM, creating different but meaningful roles for them in supporting widespread quality improvement initiatives, and providing training and development not only in TQM concepts and practices, but also in new leadership skills.

In this sense, getting middle managers to buy-in and be involved in a positive manner is viewed as key to the success of TQM [6] [24] [38] [39]. Ishikawa [38] says that middle management can contribute greatly to quality improvement but conventional organizational arrangements do not encourage their contributions. He calls for senior management to provide greater attention to encourage new roles for middle managers.

At Norand Corporation, management discovered that without middle management's committed support, the total quality process can fail. Middle management training and acceptance were made a priority. Training was created for middle managers to show them how to manage empowered employees and to become facilitators of quality improvement initiatives and coaches of employee development [36].

At Charrette Corporation, it was recognized at the outset that the new role of middle managers, especially in the transition stage, would be critical to achieving a successful implementation [35]. At Nissan UK, the supervisors have a wide range of responsibilities where people management skill features prominently. For example, supervisors are involved in staff selection, developing and training their staff and motivating and maintaining morale. They are also the channel for all communications to manufacturing staff.

\section{Training and Education}

\subsection{TQM Training}

Introducing new systems such as TQM when people do not have the fundamental skills to work in the new system is a prescription for disaster [40]. There should be no doubt that for TQM to succeed, the entire workforce must acquire new knowledge, skills and abilities. Training and education based on total quality must be planned 
and provided if this is to be realized. Oakland [20] stresses that training strategy should be addressed early alongside other strategies within the qualitypolicy. He goes on to say that training is the single most important factor in improving quality once the necessary commitment has been assured.

\section{TQM Training's Repercussion}

The importance of training and education is also echoed by other quality gurus. Ishikawa [38] says "Quality begins and ends with training" (also Imai, in Clemmer [41]). Crosby [24], Juran [42] and Feigenbaum [43] also emphasized the need for organization wide education and quality awareness programs. Top management of best organizations, recognizing the link between education and successful TQM, also focus their implementation process around it. This point is well summed up by Durrant [44] in discussing TQM initiatives at Rockware Glass Ltd., UK; "There would be more training for all in one year than the previous ten years". At Shorts Brothers, training is a number one priority [23]. Some 400 training sessions were conducted, catering for the president, the management committee and the shop floor workers. Rank Xerox has had a comprehensive training program for all its employees since the beginning of its TQ initiatives. It considers training to be an essential element in developing the TQ process throughout the company [45]. AT \& T Istel UK and Mitel Telecom Ltd. UK have also ensured that all employees are provided with formal and rigorous education at the outset of the TQM process [27] [46]. Both organizations believed that education provides a firm foundation for a common language and for understanding the organization's quality aspirations. Best companies do not just confine education and training to their shop floor employees and managers. Top executives are actively involved in the learning process themselves. Wallace Company's five top leaders each underwent more than 200 hours of intensive training in the methods and philosophy of continuous improvement. The managing director of Grundos spends an average of 30 days a year sitting in seminars with all levels of managers [3].

\subsection{Training and Education Evaluation}

It is critical for training and education programs to be linked explicitly to implementation if they are to have maximum effectiveness. Management should not assume that the new knowledge from such programs will be applied when trainees return to their workplaces. Management should have in place a system to ensure employees follow through what they have learnt when they return to their jobs after training. For example, the management at GTE (company) has put in place a system whereby employees know that they will be evaluated on the implementation of the new knowledge acquired during training. Organizations such as Honda, Corning and General Electric are other examples where new knowledge had been effectively translated into new ways of behaving. These companies actively manage the training process to ensure that it occurs by design rather than by chance.

\subsubsection{Best Time for Training}

Maximizing the impact of training by the correct timing of training programs was highlighted in a recent study of 536 TQM organizations in the USA [47]. Hence, conducting organization-wide training in TQM before the need or desire for TQM is created could have a negative impact in the TQM implementation process. Employees unable to apply their knowledge forget the details by the time they encounter a real need, and thence lose enthusiasm in the quality initiative. As training and education prepare employees for greater involvement in the organization's quality process, providing them with the right type of training is crucial. Generally, leading organizations ensure their education and training programs include both the basics of quality and TQM and the set of skills for continuous quality improvement.

\subsubsection{Training Contents}

Kano [3] stresses the importance of adapting training programs to the company's workplace. At British Steel, top management spent considerable time defining the challenges to be faced by the organization and clarifying their vision and values before embarking on training. In designing their training courses, they matched the methodologies and content to the specific culture and values of their organization [11]. At Rank Xerox, a task force was set up to develop a training curriculum to support the implementation plan. On the same note, Oakland [20] cautioned that training for quality is too important to be totally left to the so-called external quality professionals [26]. Bought-in training courses may not be compatible with the philosophies and culture of the company. In fact, some TQ organizations perceive the generic nature of off-the-rack education and training materials as a 
barrier to steady progress in the quality drive [48]. GPT Ltd. is one such organization. The literature gives a good degree of indication of the type of new skills best organizations provide for their workforce to nurture a quality ethic [11] [14] [18] [49]-[51]. A study in the USA reported that training in continuous improvement skills, interpersonal skills and leadership skills is common amongst 536 TQM organizations [47]. It is also evident from the studies that organizations are emphasizing both interactive and technical skills. According to a survey, good communication skills are one of the two employee characteristics most valued by quality-driven organizations [52]. British Airways' training for its crew is a 50-50 split between the technical and the behavioral. The latter type of training includes treating customers as individuals and taking ownership of their problems. At Charrette Corporation, training for supervisors and managers to develop the necessary facilitator skills and behavior was essential to overcome the initial uncertainty and suspicion amongst middle managers [35]. Only with a considerable amount of suitable training and education can this be achieved.

\subsection{Impact of Training and Education}

\subsubsection{Facility in Communication between the Workforce}

Organizations such as Fuji Xerox commence training for all employees immediately on hiring. They believe that putting everyone through the same TQM training provides the employees across the organization with a common language of quality and a shared way of thinking. TQM concepts are generally understood and used, making communication much easier [11].

TQM is a leadership issue at all levels. Middle managers become leaders of empowered employees, facilitators of the new management system, and coaches of new methods. Only with a considerable degree of training and education can this changed role be assumed [25]. Organizations are investing a significant amount of resources in preparing their managers to be different types of leaders. Based on a survey among UK managers [34], it was concluded that the effective training of managers may be an important factor in the success of TQM implementation.

At Nissan UK where supervisors are empowered to recruit their own staff and people management skills feature prominently in their functions, the company puts a great deal of emphasis on training and developing supervisors as leaders. In addition to standard training elements, professional programs conducted cover personal effectiveness and impart knowledge required by a supervisor in one function which is different from that needed by his or her peer in another function [53].

\subsubsection{Training of Trainer}

It produced its own education package comprising a work book, manual and videos. In many TQ organizations that conduct internal training, cascading of training is common [54]. This basically involves a number of managers and supervisors who, after undergoing training and education themselves, are selected to be trained as course instructors for internal training. These trainers then develop their own training package best suited to their team's needs. In some organizations, the process starts at the top [9]. The CEO, who is trained first, trains managers who report to him or her, and who in turn teach their immediate staff and so forth.

By accepting responsibility for and conducting training courses themselves, managers are seen as visible supporters and get buy-in from their "students". Training will have more impact as a result as employees, seeing that management is committed; will also be more willing to get involved. In the process, managers also develop self-discipline and expertise in promoting TQM within the organization [55].

GPT Ltd. UK, call such training "family group training" [48]. The majority of its training workshops were designed and run by line managers. The cascading approach was used at Ilford Ltd. to great effect [56]. A top management committee delivered the training, starting with themselves and followed by the next level. This level then trained their reporting managers. At Southern Pacific Lines, internal staffs deliver most of the formal quality training for the company's 23,000 employees [14]. Rank Xerox Limited, whose first-line managers also worked with their staff during training, sees the line management ownership of the training process as critical to effective continuing implementation [57].

In some TQ organizations, however, training is led by employees who are recognized by the management as having particular interpersonal skills. This is done without reducing or compromising the role of the work group leader in any way. At LeaRonal (UK), training achieved a high degree of success using dedicated in-house trainers [4]. 


\subsection{Effect of Training Quality}

\subsubsection{Protect Training Materials}

Before they develop tailor-made training packages, some organizations start by using training materials put together by external consultants, gradually reducing their involvement. BP Chemicals UK, started by using the Crosby program [58]. While they retained Crosby's key principles and philosophy, the training materials are now their own. After getting training help externally in the initial years, Paul Revere Insurance Group has now taken responsibility for its own training [18]. At Shorts Brothers, the training was initially consultant-led [16]. In the later stages, the employees took ownership of all courses. The three organizations view the ownership of the training process as an important factor in their quality initiatives.

In almost all the 20 best companies surveyed in the USA, Europe and the Far East, Bertsch and Williams [9] found that quality training is frequently conducted by line managers with consultants used sparingly and for specific short-term assignments. The use of cascade systems is common.

\subsubsection{Reward of Training Employees}

In TQ organizations, most employees receive a substantial amount of annual training. Employees of Baldrige applicants receive 40 to 80 hours of training per year [59]. At Grundos, an average of 4 percent of employees' working time is devoted to training [3]. In terms of training expenditures, top American organizations, Baldrige applicants included, commit 2 - 5 percent of total corporate payroll.

In the USA, several top companies is recognizing the importance of training and education and have come together to form a cooperative venture to identify training's best practices and generate comparative data to set a standard for their individual efforts. The American Society for Training and Development's Benchmarking Forum is represented by 37 companies, and includes many Baldrige winners. One of their motives is a desire to learn how to adopt or adapt training practices that clearly provide a competitive advantage [60].

\section{Conclusion}

For the smooth run of any institute and organization we need a path and guidance, which path we can follow and that guidance can provide us a clear path to achieve our goals, my paper described that path as well as the management system. It was concluded that the effective training of managers might be an important factor in the success of TQM implementation. After my study, I can conclude that training is the back bone for the improvement of management system; training is not only for lower employees but also for the high ranking employees. Leadership managers also need training for the smooth running of any organization. Secondly, cooperation is also necessary among all employees between the same level staffs as well as cooperation between leadership and lower level employees.

\section{Acknowledgements}

This research is intended to International Education College, China University of Geosciences (Wuhan) as thanks from Madagascar community.

\section{References}

[1] Easton, G.S. (1993) The 1993 State of US Total Quality Management: A Baldrige Examiner’s Perspective. California Management Review, 35, 32-54. http://dx.doi.org/10.2307/41166742

[2] Powers, V. (1994) The Sweet Smell of Success. Continuous Journey, October/November, 18-24.

[3] Binney, G. (1992) Making Quality Work: Lessons from Europe’s Leading Companies. The Economist Intelligence Unit, London.

[4] Smith, S. (1994) The Quality Revolution. Management Books Ltd., Didcot.

[5] Kolesar, P.J. (1993) Vision, Values, Milestones: Paul O’Neill Starts Total Quality at Alcoa. California Management Review, 35, 133-165. http://dx.doi.org/10.2307/41166748

[6] Olian, J.D. and Rynes, S.L. (1991) Making Total Quality Work: Aligning Organizational Processes, Performance Measures, and Stakeholders. Human Resource Management, 30, 303-333. http://dx.doi.org/10.1002/hrm.3930300303

[7] Ramirez, C. and Loney, T. (1993) Baldrige Award Winners Identify the Essential Activities of a Successful Quality Process. Quality Digest, January, 38-40. 
[8] Bertram, D. (1991) Getting Started in Total Quality Management. Total Quality Management, 2, 279-282. http://dx.doi.org/10.1080/09544129100000032

[9] Bertsch, B. and Williams, R. (1994) How Multinational CEOs Make Change Programme Stick. Long Range Planning, 27, 3-11. http://dx.doi.org/10.1016/0024-6301(94)90223-2

[10] Barker, R.L. (1991) Basic Improvement Tools and Total Quality Management. In: Oakland, J.S., Ed., Total Quality Management, Proceedings of the 4th International Conference, Warwick, IFS Ltd, Bedford.

[11] Johnston, C.G. and Daniel, M.J. (1991) Customer Satisfaction through Quality: An International Perspective. The Conference Board of Canada, Ottawa.

[12] George, D. (1990) The Routine Involvement of Senior Managers in the Quality Improvement Process. In: Oakland, J.S., Ed., Proceedings of the 3rd International Conference on Total Quality Management, Warwick, IFS Ltd., Bedford.

[13] Browning, S.A. and Shaw, W.N. (1990) Employees' Views of TQM at Two Hewlett-Packard Manufacturing Plants. In: Oakland, J.S., Ed., Proceedings of the 3rd International Conference on Total Quality Management, Warwick, IFS Ltd., Bedford.

[14] Carman, J.M. (1993) Continuous Quality Improvement as a Survival Strategy: The Southern Pacific Experience. California Management Review, 35, 118-132. http://dx.doi.org/10.2307/41166747

[15] Wiggenhorn, W. (1990) Motorola U: When Training Becomes an Education. Harvard Business Review, 68, 71-83.

[16] Oakland, J.S. and Porter, L. (1994) Cases in Total Quality Management. Butterworth-Heinemann, Oxford.

[17] Durrant, P.W. (1990) TQM and The Cultural Changes Required. In: Oakland, J.S., Ed., Proceedings of the 3rd International Conference on Total Quality Management, Warwick, IFS Ltd., Bedford.

[18] Bank, J. (1992) The Essence of Total Quality Management. Prentice-Hall, London.

[19] Juran, J.M. (1993) Made in USA: A Renaissance in Quality. Harvard Business Review, 71, 42-50.

[20] Oakland, J.S. (1993) Total Quality Management. Butterworth-Heinemann, Oxford.

[21] Haksever, C. (1996) Total Quality Management in the Small Business Environment. Business Horizons, 39, 33-40. http://dx.doi.org/10.1016/S0007-6813(96)90021-X

[22] Reeves, C.A. and Bednar, D.A. (1993) What Prevents TQM Implementation in Health Care Organizations? Quality Progress, 26, 41-44.

[23] Quality Progress (1994) Companies That Link Quality to Reward Program Report Success. Quality Progress, 27, 15, 18.

[24] Crosby, P. (1989) Let’s Talk Quality: 96 Questions That You Always Wanted to Ask Phil Crosby. McGraw-Hill, New York.

[25] Townsend, P.L. and Gebhardt, J.E. (1992) Quality in Action. John Wiley \& Sons, New York.

[26] Smith, P.K. and Tee, M.R. (1990) Total Quality—The Issues and Realities for a Leading Supplier of Advanced Surface Treatment Technology. In: Oakland, J.S., Ed., Proceedings of the 3rd International Conference on Total Quality Management, Warwick, IFS Ltd., Bedford.

[27] Boyer, S.M. (1991) Total Quality Management and New Product Development. Total Quality Management, 2, $283-290$. http://dx.doi.org/10.1080/09544129100000033

[28] Deming, W.E. (1986) Out of the Crisis. MIT Centre for Advanced Engineering Study, Cambridge.

[29] Juran, J.M. (1991) Juran on Quality by Design. Free Press, New York.

[30] Zink, K.J. (1995) Total Quality Management and People Management. In: Kanji, G.K., Ed., Total Quality Management: Processing of the 1st World Congress, Chapman \& Hall, London.

[31] Nadkarni, R.A. (1995) A Not-So-Secret recipe for Successful TQM. Quality Progress, 28, 91-96.

[32] Bemowski, K. (1992) Carrying on the P\&G Tradition. Quality Progress, 25, 21-25.

[33] Bemowski, K. (1994) Baldrige Award Recipients Share Their Expertise. Quality Progress, 28, 35-40.

[34] Wilkinson, A., Redman, T. and Snape, E. (1994) Quality Management and the Manager. Employee Relations, 16, 6270. http://dx.doi.org/10.1108/01425459410054934

[35] Manz, C.C. and Sims, H.P. (1993) Business without Bosses. John Wiley, New York.

[36] Wacker, K.A. (1993) Uncommon Common Sense. Quality Progress, 26, 97-100.

[37] Quality Progress (1993) Middle Managers Can Inhibit TQM. Quality Progress, 26, 16,18.

[38] Ishikawa, K. (1985) What Is Total Quality Control? The Japanese Way. Prentice-Hall, Englewood Cliffs.

[39] McDermott, L. (1993) Jump-Starting Managers on Quality. Training \& Development, 47, 37. 
[40] Dumas, R. (1989) Organizational Quality: How to Avoid Common Pitfalls. Quality Progress, 22, 41-44.

[41] Clemmer, J. (1990) Firing on All Cylinders. Judy Piatkus Publishers, London.

[42] Juran, J.M. (1974) Quality Control Handbook. McGraw-Hill, London.

[43] Feigenbaum, A.V. (1961) Total Quality Control. McGraw-Hill, London.

[44] Durrant, P.W. (1990) TQM and The Cultural Changes Required. In: Oakland, J.S., Ed., Proceedings of the 3rd International Conference on Total Quality Management, Warwick, IFS Ltd., Bedford.

[45] Cullen, J. and Hollingum, J. (1987) Implementing Total Quality. IFS Ltd., Bedford.

[46] Hutt, G. (1990) Quality—The Proper Way of Managing. In: Oakland, J.S., Ed., Proceedings of the 3rd International Conference on Total Quality Management, Warwick, IFS Ltd., Bedford.

[47] DDI (1994) TQM: Forging Ahead or Falling behind—A Study of Quality Practices. Development Dimensions International Inc., Bridgeville.

[48] Cashbourne, B.R. (1991) Organizing for Total Quality Management. In: Oakland, J.S., Ed., Proceedings of the 4th International Conference on Total Quality Management, Warwick, Bedford, UK, IFS Ltd.

[49] Sanford, R.L. (1992) Baxter Healthcare Uses Its Own Quality Award to Help Achieve Excellence. National Productivity Review, 12, 37-43. http://dx.doi.org/10.1002/npr.4040120106

[50] Oakland, J.S. and Beardmore, D. (1995) Best Practice Customer Service. Total Quality Management, 6, 135-148. http://dx.doi.org/10.1080/09544129550035486

[51] Westbrook, R. and Barwise, P. (1995) Total Quality Management in Leading Fast-Moving Consumer Goods Companies. Total Quality Management, 6, 365-382. http://dx.doi.org/10.1080/09544129550035314

[52] Quality Progress (1995) Workforce Study Identifies Most Valued Employee Characteristics. Quality Progress, 28, 14.

[53] Vallely, I. (1993) Why Supervisors Can with Nissan. Works Management, 18-21.

[54] Bendell, T., Boulter, L. and Kelly, J. (1993) Benchmarking for Competitive Advantage. Pitman Publishing, London.

[55] Kanji, G.K. and Asher, M. (1993) Total Quality Management Process-A Systematic Approach. Advances in Total Quality Management Series. Carfax Publishing, Abingdon.

[56] Hunt, W. and Hillman, G.P. (1990) Achieving the Real Culture Change Necessary for TQM. In: Oakland, J.S., Ed., Proceedings of the 3rd International Conference on Total Quality Management, Warwick, IFS Ltd., Bedford.

[57] Wright, J. (1988) Rank Xerox Approach to Implementation. In: Oakland, J.S., Ed., Proceedings of the 1st International Conference on Total Quality Management, Warwick, IFS Ltd., Bedford.

[58] Stark, J.A.L. (1990) Experience of TQM at BP Chemicals. In Oakland, J.S., Ed., Proceedings of the 3rd International Conference on Total Quality Management, Warwick, IFS Ltd., Bedford.

[59] Easton, G.S. (1993) The 1993 State of US Total Quality Management: A Baldrige Examiner’s Perspective. California Management Review, 35, 32-54. http://dx.doi.org/10.2307/41166742

[60] Kimmerling, G. (1993) Gathering Best Practices. Training \& Development, 47, 29-36. 
Scientific Research Publishing (SCIRP) is one of the largest Open Access journal publishers. It is currently publishing more than 200 open access, online, peer-reviewed journals covering a wide range of academic disciplines. SCIRP serves the worldwide academic communities and contributes to the progress and application of science with its publication.

Other selected journals from SCIRP are listed as below. Submit your manuscript to us via either submit@scirp.org or Online Submission Portal.
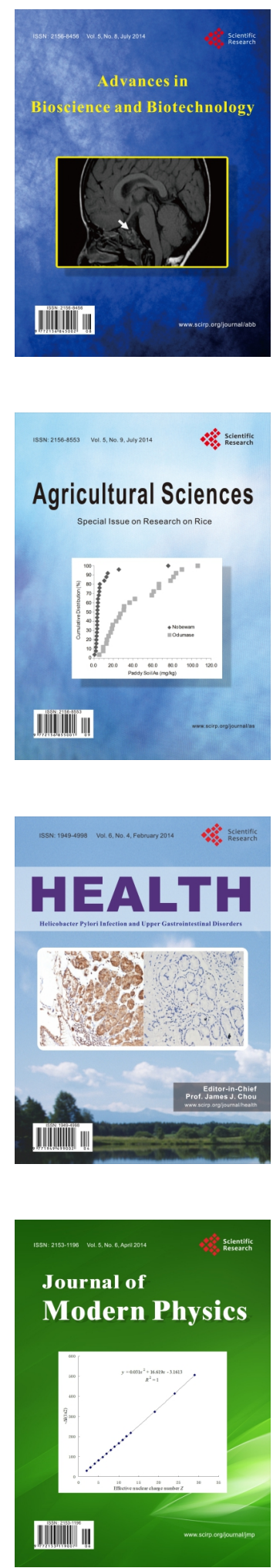
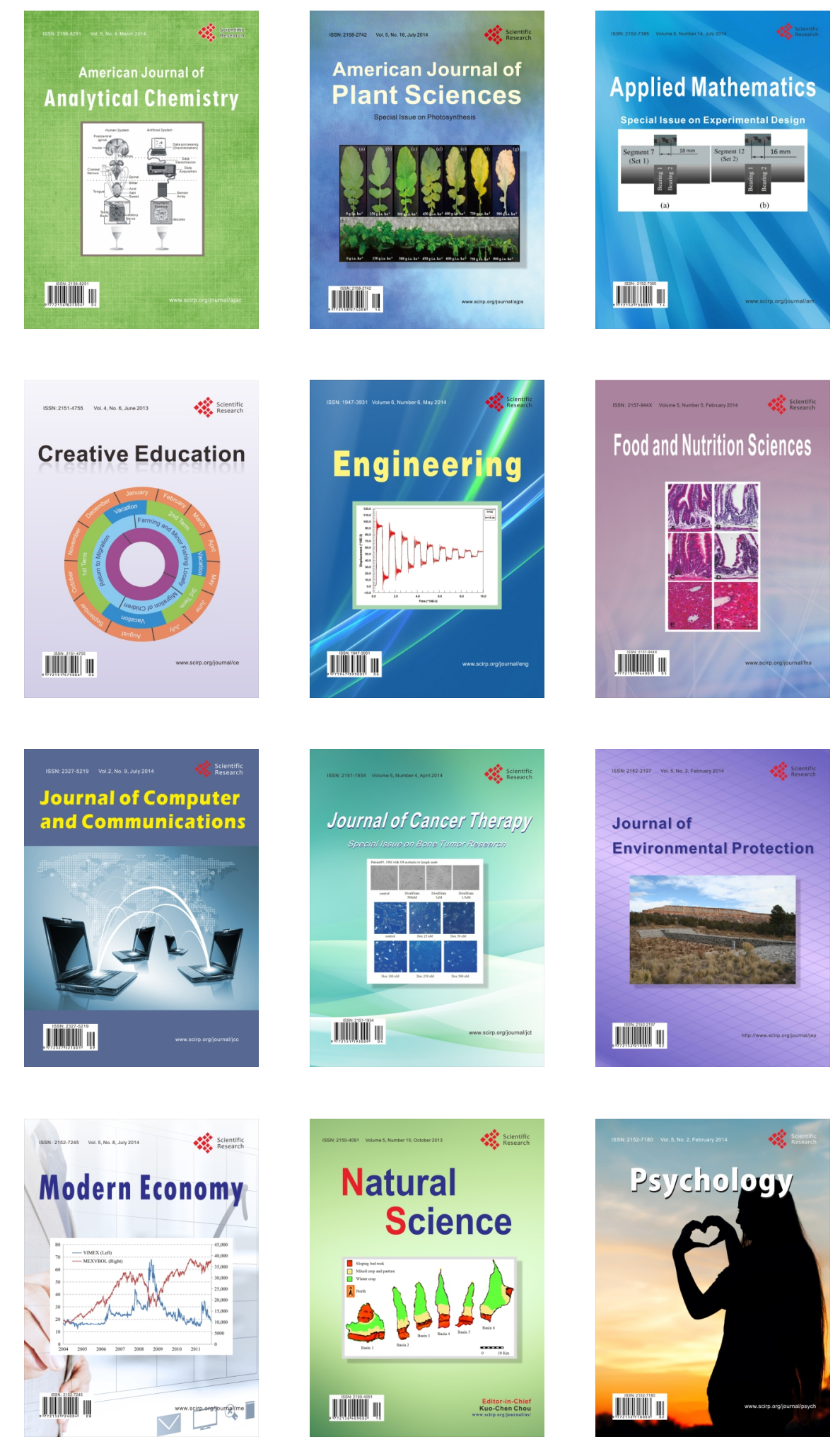